\title{
HUBUNGAN ANTARA MITOS DENGAN KETIDAKBERHASILAN PEMBERIAN ASI EKSLUSIF DI BPM "L" KECAMATAN BATUJAJAR KABUPATEN BANDUNG BARAT
}

\author{
Siti Maulida ${ }^{1}$, Ira Kartika ${ }^{2}$ \\ irakartika45@yahoo.co.id \\ ${ }^{1,2}$ Program Studi D3 Kebidanan STIKes Dharma Husada Bandung
}

\begin{abstract}
A B S T R A K
Permasalahan utama dalam pemberian ASI ekslusif diantaranya adalah Pengetahuan, Pendidikan, pekerjaan, umur dan sosial budaya tetapi yang paling berpengaruh di masyarakat yaitu sosial budaya yang berupa kebiasaan dan kepercayaan seseorang dalam pemberian ASI eksklusif. Tujuan dari penelitian untuk mengetahui hubungan antara mitos dengan ketidakberhasilan pemberian ASI Ekslusif. Metode penelitian ini menggunakan jenis penelitian deskriptif. Populasi dalam penelitian inia dalah 30 responden. Pengambilan sample menggunakan teknik aksidental berjumlah 30 responden

Hasil penelitian diperoleh hasil bahwa mitos ASI ekslusif di BPM L lebih banyak pada kriteria percaya, yaitu sebanyak 18 responden $(60,0 \%)$. Berdasarkan ketidakberhasilan ASI ekslusif dan tidak ASI Ekslusif lebih banyak pada kriteria tidak ASI Ekslusif, yaitu 21 responden $(70,0 \%)$. Frekuensi mitos terbesar responden adalah kategori percaya, yaitu sebanyak 18 responden $(60,0 \%)$, jumlah mitos percaya yang dikategorikan tidak ASI sebanyak 14 responden $(77,8 \%)$ yang ASI 7 rsponden $(58,3 \%)$, jumlah mitos tidak percaya yang dikategorikan tidak ASI sebanyak 7 responden $(58,3 \%)$ yang ASI 5 rsponden $(41,7 \%)$. Hasil uji statistic didapatkan nilai $\mathrm{P}=0.003$ maka Ho ditolak dan dapat disimpulkan ada hubungan antara mitos dengan ketidak berhasilan pemberian ASI Ekslusif.
\end{abstract}

Kata kunci : ASI, ketidakberhasilan pemberian ASI, social budaya

\section{PENDAHULUAN}

Pemberian ASI secara ekslusif bagi

bayi bukan sekedar untuk memberikan nutrisi pada si bayi, tetapi lebih untuk mengoptimalkan pertumbuhan dan perkembangan otak si bayi tersebut. Kecerdasan seorang anak, menurut penelitian, mencapai 50 persen pada usia 0-4 tahun. Hingga usia 8 tahun kecerdasannya meningkat sampai 80 persen, dan puncaknya (100 persen) di usia 18 tahun. ${ }^{1}$ Permasalahan utama dalam pemberian ASI ekslusif adalah sosial budaya yaitu berupa kebiasaan dan kepercayaan seseorang dalam pemberian ASI eksklusif.

Hasil penelitian menunjukkan bahwa mitos berhubungan dengan pemberian ASI eksklusifyaitu sebesar $50 \%$ responden dengan budaya yang baik terkait pemberian ASI eksklusif dan 60,4\% responden dengan budaya yang kurang baik tidak memberikan ASI eksklusif. ${ }^{2}$

Pemberian ASI eksklusif masih sangat dipengaruhi oleh kebudayaan setempat dimana sebagian besar 
penduduknya masih memegang teguh adat istiadat. Berdasarkan studi pendahuluan dilakukan penelitian dengan metode wawancara di BPM L Kec. Batujajar Kab.Bandung Barat ada 8 orang ibu yang tidak mau memberikan ASI Eksklusif karena adanya mitos bahwa 4 ibu mengatakan bahwa bayi akan rewel karena lapar bila diberi ASI saja. 2 ibu mengatakan menyusui menyebabkan payudara menjadi kendur, 2 ibu mengatakan payudara berukuran kecil tidak dapat menghasilkan air susu yang cukup. Adapun mitos yang berkembang tentang pemberian ASI bagi bayi, anggapan ini sering menjadi kendala bagi ibu, yang akhirnya mencari alternatif lain.

\section{METODE PENELITIAN}

Penelitian yang di lakukan ini adalah penelitian non eksperimen dengan rancangan penelitian cross sectional. Sampel yang di gunakan dalam penelitian ini 30 ibu yang mempunyai bayi usia 7-12 bulan. Instrumen yang di gunakan adalah kuesioner dengan skala gutman. Kuesioner dibuat dalam bentuk checklist yang terdiri dari 25 pertanyaan. Metode analisa data yang digunakan untuk mengolah data dengan menggunakan "chi square test". Penelitian ini dilaksanakan di BPM Bidan L Kec. Batujajar Kab.Bandung Barat, dilaksanakan pada bulan Mei 2017.

HASIL DAN PEMBAHASAN

HASIL

\section{Tabel 1}

Distribusi Frekuensi Kepercayaan Mitos ASI Ekslusif

\begin{tabular}{clcc}
\hline No & Kategori & $\mathrm{F}$ & $\%$ \\
\hline 1 & Percaya & 18 & 60.0 \\
2 & Tidak Percaya & 12 & 40.0 \\
\hline & Total & 30 & 100.0 \\
\hline
\end{tabular}

Berdasarkan tabel 1 didapatkan hasil bahwa mitos ASI ekslusif lebih banyak ada pada kriteria percaya, yaitu 18 responden $(60,0 \%)$.

Tabel 2

Distribusi Frekuensi gambaran pemberian ASI

\begin{tabular}{clcc}
\hline No & Kategori & F & $\%$ \\
\hline 1 & Tidak ASI & 21 & 70.0 \\
& Ekslusif & & 30.0 \\
2 & ASI Ekslusif & 9 & 100 \\
\hline & Total & 30 &
\end{tabular}

Berdasarkan tabel 2. didapatkan hasil bahwa pemberian ASI ada pada kriteria tidak ASI Ekslusif, yaitu dengan 21 responden $(70,0 \%)$. 
Tabel 3

Hubungan antara Mitos dengan Ketidakberhasilan Pemberian ASI Ekslusif

\begin{tabular}{cccccccc}
\hline \multirow{2}{*}{ Mitos } & \multicolumn{4}{c}{ ASI Ekslusif } & \multicolumn{2}{c}{ Total } & \multirow{2}{*}{ P Value } \\
\cline { 2 - 7 } & \multicolumn{2}{c}{ Tidak ASI } & \multicolumn{2}{c}{ ASI } & & \\
\cline { 2 - 7 } & $\mathrm{n}$ & $\%$ & $\mathrm{~N}$ & $\%$ & $\mathrm{n}$ & $\%$ & \\
\hline Percaya & 14 & 77.8 & 4 & 22,2 & 18 & 100 & 0.003 \\
Tidak percaya & 7 & 58.3 & 5 & 41,7 & 12 & 100 & \\
\hline Jumlah & $\mathbf{2 1}$ & $\mathbf{7 0 , 0}$ & $\mathbf{9}$ & $\mathbf{3 0 , 0}$ & $\mathbf{8 0}$ & $\mathbf{1 0 0}$ & \\
\hline
\end{tabular}

Dilihat dari tabel 3 diketahui bahwa frekuensi mitos terbesar responden adalah kategori percaya, yaitu sebanyak 18 responden $(60,0 \%)$, jumlah mitos percaya yang dikategorikan tidak ASI sebanyak 14 responden $(77,8 \%)$ yang ASI 7 responden $(58,3 \%)$, jumlah mitos tidak percaya yang dikategorikan tidak ASI sebanyak 7 responden $(58,3 \%)$ yang ASI 5 responden $(41,7 \%)$. Hasil uji statistik didapatkan nilai $\mathrm{P}=0.003$ maka Ho ditolak dan dapat disimpulkan ada hubungan antara mitos dengan ketidakberhasilan pemberian ASI Ekslusif.

\section{PEMBAHASAN}

\section{Kepercayaan Mitos ASI Ekslusif}

Berdasarkan hasil penelitian bahwa mitos ASI ekslusif di BPM Bidan L Kec. Batujajar Kab. Bandung Barat periode Mei 2017 lebih banyak ada pada kriteria percaya, yaitu dengan 18 responden $(60,0 \%)$. mitos atau kepercayaan merupakan hambatan untuk tindakan menyusui yang normal, diantaranya : a. kolostrum tidak baik bahkan bahaya untuk bayi b. bayi membutuhkan teh khusus atau cairan lain sebelum menyusui c. bayi tidak mendapatkan cukup makanan atau cairan bila hanya diberi kolostrum atau ASI. Sebagian ibu percaya bahwa bayi membutuhkan banyak makanan dan cairan untuk Pertumbuhannya, sehingga seorang ibu akan berusaha memberikan makanan selain ASI untuk mencukupi kebutuhan tersebut. ${ }^{3}$

\section{Gambaran pemberian ASI}

Berdasarkan hasil penelitian bahwa pemberian ASI lebih banyak pada kriteria tidak ASI Ekslusif, yaitu dengan 21 responden $(70,0 \%)$. ASI Eksklusif adalah bayi hanya diberi ASI saja selama 6 bulan, tanpa tambahan cairan lain seperti susu formula, jeruk, madu, air teh, dan air putih, serta tanpa tambahan makanan padat sepeerti pisang, bubur susu, biscuit, bubur nasi, dan nasi tim. Setelah 6 bulan baru mulai diberikan makanan pendamping ASI (MPASI). ${ }^{7}$ 
Pemberian ASI eksklusif masih sangat dipengaruhi oleh kebudayaan setempat dimana sebagian besar penduduknya masih memegang teguh adat istiadat. Selain alasan utama Ibu tidak memberikan ASI secara eksklusif yaitu faktor umur, pengetahuan, pendidikan, pekerjaan, penghasilan dan lain-lain. ${ }^{4}$

Rendahnya keinginan dan pemahaman ibu tentang pentingnya ASI eksklusif selama 6 bulan pertama, hal ini dikarenakan kurangnya informasi dan pengetahuan yang dimiliki oleh para ibu mengenai segala nilai plus nutrisi dan manfaat yang terkandung dalam ASI. Tingkat pengetahuan masyarakat tentang kesehatan akan mempengaruhi perilaku masyarakat dibidang kesehatan. Tidak hanya perilaku saja, masih ada faktor-faktor lain

\section{Hubungan antara mitos dengan} ketidakberhasilan pemberian ASI Ekslusif

Berdasarkan hasil penelitian bahwa frekuensi mitos terbesar adalah kategori percaya, yaitu sebanyak 18 responden $(60,0 \%)$, jumlah mitos percaya yang dikategorikan tidak ASI sebanyak 14 responden $(77,8 \%)$ yang ASI 7 responden $(58,3 \%)$, jumlah mitos tidak percaya yang dikategorikan tidak ASI sebanyak 7 responden $(58,3 \%)$ yang ASI 5 rsponden $(41,7 \%)$.

Hasil uji statistik didapatkan nilai $\mathrm{P}=0.258$ maka keputusanya Ho ditolak dan dapat disimpulkan ada hubungan antara mitos dengan ketidakberhasilan pemberian ASI Ekslusif di BPM Kec. Batujajar Kab. Bandung Barat.

Permasalahan utama dalam pemberian ASI ekslusif adalah sosial budaya yaitu berupa kebiasaan dan kepercayaan seseorang dalam pemberian ASI eksklusif. Adapun kebiasaan ibu yang tidak mendukung pemberian ASI adalah kebiasaan memberikan susu formula sebagai pengganti $^{5}$

ASI apabila bayi ditinggal ibunya atau bayi rewel dan kebiasaan memberikan makanan padat/sereal pada bayi sebelum usia 6 bulan agar bayi cepat kenyang dan tidak rewel sedangkan kepercayaan ibu yang tidak mendukung pemberian ASI adalah seperti adanya kepercayan minum wejah (sejenis minuman dari daundaunan tertentu) dengan keyakinan bahwa ASI akan lebih banyak keluar. Salah satu mitos kebudayaan yang beredar dalam pemberian ASI eksklusif yaitu salah kaprah yang menganggap bahwa menyusui merupakan perilaku primitif. ${ }^{6}$ 
Hasil penelitian tentang hubungan antara pengetahuan dan mitos dengan pemberian ASI eksklusif, menunjukkan bahwa mitos berhubungan dengan pemberian ASI eksklusif yaitu sebesar $50 \%$ responden dengan budaya yang baik terkait pemberian ASI eksklusif dan $60,4 \%$ responden dengan budaya yang kurang baik tidak memberikan ASI eksklusif. ${ }^{8}$
Roesli U. Mengenal ASI eksklusif. Jakarta: Trubus Agriwijaya; 2009: 2640

Rosita S. ASI untuk kecerdasan bayi. Yogyakarta: Ayyana; 2011

\section{SIMPULAN}

Terdapat hubungan yang bermakna antara mitos dengan ketidakberhasilan pemberian ASI Ekslusif, secara statistik menunjuakan bahwa $(\mathrm{p}<0,05 ; 0.003)$.

\section{DAFTAR PUSTAKA}

Cornelia M,Turnip O,Wahyuningsih $\mathrm{H}$, Heni J,Palupi R. Kelompok pendukung ibu.Jakarta:MercyCorps;2008: 1-39

Departemen Kesehatan Republik Indonesia. Pelatihan konseling menyusui. Jakarta:Depkes;2007

Hidayanti H. Hubungan sosial budaya dengan keberhasilan pemberian asi ekslusif pada ibu menyusui di posyandu. Yogyakarta: Digilib unisayogya: 2013

Ikatan Dokter Anak Indonesia. Indonesia Menyusui. Jakarta: Badan Penerbit IDAI; 2011

Oktaviani. Hubungan pengetahuan dan sosial budaya dengan pemberian asi eksklusif; 2011

Roesli U. Bayi Sehat Berkat Asi Eksklusif. Jakarta: Elex Media Komputindo; 2004 